Working Paper No. 608, 2003

Privatization Policy in an International Oligopoly

by Pehr-Johan Norbäck and Lars Persson

IUI, The Research Institute of Industrial Economics

P.O. Box 5501

SE-114 85 Stockholm

Sweden 


\title{
Privatization Policy in an International Oligopoly
}

\author{
Pehr-Johan Norbäck ${ }^{*}$ \\ Research Institute of Industrial Economics \\ Lars Persson \\ Research Institute of Industrial Economics and CEPR
}

November 25, 2003

\begin{abstract}
This paper studies privatization policy in an international oligopoly. The argument that equal treatment of foreign investors will be detrimental to domestic welfare by shifting profits from domestic to foreign firms is shown to be less relevant in privatization auctions than in greenfield FDI models, since these profit shifts are partly paid for by the foreign firms in the bidding competition. Effects of local equity requirements, trade and investment policies are also studied. It is, for instance, shown that small local equity requirements are likely to be beneficial but large ones are counterproductive, by preventing welfare-enhancing foreign acquisitions.
\end{abstract}

Keywords: Privatization, Acquisitions, National Treatment, Investment Policy, Trade Policy.

JEL classification: F23, L13, L33

*We have benefitted from useful comments from participants in seminars at the Institute for International Economic Studies (Stockholm), WZB (Berlin), 2000 CEPR and IUI Mergers and Competition Workshop (Stockholm), and European University Institute (Florence). Thanks to Christina Lönnblad for improving the language. Financial support from the Marianne and Marcus Wallenberg Foundation, and Tom Hedelius' and Jan Wallander's Research Foundations, is gratefully acknowledged.

†Pehr-Johan Norbäck and Lars Persson, Research Institute of Industrial Economics, P.O. Box 5501, SE-114 85 Stockholm. E-mail: larsp@iui.se and PJN@iui.se, Internet: www.iui.se, Fax.+46-8-6654599. 


\section{Introduction}

Privatizations have become an important part of industrial restructuring in all parts of the world. Since 1990, European governments have sold more than $\$ 450$ billion-worth of state assets in many different sectors, including the banking, insurance, telecommunication and automobile industries. Many countries also announce substantial forthcoming privatizations.

Foreign competition is an important element in many of these sales. In the 1990's, about $30 \%$ of the privatized firms in Europe were acquired by foreign investors. ${ }^{1}$ Despite positive effects of foreign competition being acknowledged in privatizations ${ }^{2}$, there is a concern that acquisitions by foreign firms will be detrimental to domestic welfare. Some countries restrict the right of foreign individuals and firms to acquire domestic firms, or apply special restrictions to foreign firms in certain industries, as is the case in Malaysia and the Republic of Korea, for example. ${ }^{3}$ On the other hand, many countries negotiate over socalled "National Treatment" (NT) clauses, which set out the commitments of countries to treat foreign-controlled firms operating in their territories no less favorably than domestic enterprises in similar situations. ${ }^{4}$ In the policy debate, NT has been questioned on the grounds that it might lead to foreign direct investment (FDI), which "crowds out" domestic

\footnotetext{
${ }^{1}$ See Thompson Financial Securities.

${ }^{2}$ Foreign acquisitions might lead to a challenge of established domestic oligopolies by creating effective local rivals, a transfer of new or better technology, and higher sales revenues.

${ }^{3}$ But the practise of countries in this respect has also changed over time. For instance, by May 1998, the restrictions on foreign acquisitions of domestic shares in the stock market, and the restrictions on M\&As by foreigners in the Republic of Korea had been abolished. The new investment policy still favors greenfield investment through, for instance, different tax treatments of M\&A investments, however (World Investment Report (WIR), 2000).

${ }^{4}$ For instance, Bolivia and the United States signed a bilateral treaty in April 1998, including a national treatment clause. Article II.1 in this treaty states: "With respect to the establishment, acquisition, expansion, management, conduct, operation and sale or other disposition of covered investments, each Party shall accord treatment no less favorable than it accords, in like situations, to investments in its territory of its own nationals or companies (hereinafter "national treatment")..." (WIR 1999).
} 
investments and shifts profits from domestic to foreign firms. ${ }^{5}$

In this paper, we compare a national treatment (NT)-policy, allowing both foreign and domestic acquisitions of the privatized firm, to a protectionist (P)-policy, only allowing domestic acquisitions, assuming that the only source of difference between the foreign and the domestic firm is that the foreign firm is initially located outside the domestic country and therefore faces a trade cost if it does not invest locally.

We then show that the negative crowding out effects of having an NT-policy are partly mitigated when entry takes place through an acquisition in a privatization auction. ${ }^{6}$ The reason is that the foreign firm pays a price for the state assets equal to the domestic firm's valuation of the assets. But the domestic firm's valuation corresponds exactly to the negative impact on this firm of the decline in profits due to the foreign acquisition. This result illustrates a fundamental difference between foreign entry in the context of acquisition and greenfield investment, i.e. investment in new assets. In the case where only greenfield entry is an option, the foreign firm will pay a fixed entry cost which only covers the opportunity cost in terms of factor inputs. ${ }^{7}$ In contrast to the case of acquisition entry, the negative effect on the domestic firm's profit is not "paid for".

It is also shown that an NT clause tends to lead to higher total aggregate profits for domestic and foreign firms in concentrated markets, since the privatization auction is shown to be conducive to high total industry profits in such markets. ${ }^{8}$ Moreover, the consumer surplus tends to be higher under the NT-policy, since foreign entry is facilitated

\footnotetext{
${ }^{5}$ WIR 1999.

${ }^{6}$ In practise, different types of measures have been used to privatize former state-owned enterprises. However, developed countries mostly employed various kinds of auctions to sell state-owned enterprises to the highest bidder, see Schmidt and Schnitzer (1997).

${ }^{7}$ This is motivated by the fact that greenfield assets are created by new investments and that the supply of inputs (labor and capital) used to create greenfield assets are inputs used in many other industries in the economy. The investor in a particular industry could then be seen as price taker, i.e. facing an infinitely elastic supply.

${ }^{8}$ Note that many privatizations takes place in markets where production takes place under increasing return to scale and where entry barriers are high.
} 
and thereby the product market competition is also strengthened. Consequently, both domestic and world welfare tends to be higher under a NT-policy compared to the Ppolicy.

So far we have compared two extreme policies, a fully discriminatory policy with a national treatment policy. But other types of policies might be relevant alternatives. Some countries have local equity requirements (LER) requiring that an investing foreign firm must have a legislated share of domestic ownership. It is then shown that in privatizations, a LER can increase domestic welfare by increasing domestic equity rents while not affecting the sales price of the privatized firm or the product market interaction. However, it is also shown that a LER could be counterproductive, leading to the prevention of welfareenhancing foreign acquisitions.

Many privatizations take place in industries that have been subject to strategic trade and investment policies, for example the steel, telecommunication and automobile industries. In a framework where a foreign firm could enter by acquisition in a privatization auction or greenfield, or could serve the market by exports, we show that trade and investment policies will not only affect trade and greenfield investment patterns, but also the buyer's identity and the selling price in the privatization. It is, for instance, shown that investment subsidies to foreign firms might be counterproductive, since these do not necessarily increase investments but may only reduce the sales price of the state assets.

To our knowledge, no paper in the theoretical privatization literature studies privatization policy in a situation where potential buyers compete in an international oligopoly. ${ }^{9}$ This paper might also be seen as a contribution to the literature on the relation between different types of policies towards foreign firms, which we extend by considering the interaction between competition (privatization), investment, and trade policy. ${ }^{10}$

\footnotetext{
${ }^{9}$ For overviews of the privatization literature see, for instance, Schmidt and Schnitzer (1997) and Vickers and Yarrow (1991).

${ }^{10}$ See Horn and Levinsohn (2001) for an overview of the literature on merger and trade policy. This literature treats mergers as exogenously determined. See Horn and Persson (2001) for a contribution where mergers are endogenously determined and effects of trade barriers are discussed, and Huck and Konrad
} 
The model is spelled out in Section 2, and in Section 3 we derive the equilibrium market structure. In Section 4, we make some observations concerning privatization, investment and trade policies. Section 5 concludes. Finally, most proofs appear in the Appendix.

\section{The Model}

There are two countries, country $\mathrm{H}$ and country F. At the outset, a state-owned enterprise and a privately owned domestic firm, $d$, are located in a market in country H. There is also a foreign firm, $f$, located in country F. Initially, each private firm possesses one unit of private assets, $k_{P}$, in its respective home country. In the following, we shall focus on the market in country $\mathrm{H}$, where the government will liberalize the market through a program with two distinct measures: (i) selling the state assets, and (ii) allowing for new plants to be opened by foreigners, i.e. allowing for greenfield investments by abolishing investment restrictions.

As illustrated in Figure 2.1, interaction takes place in four stages. In the first stage, the government decides whether to use a national treatment (NT)-policy in the privatization auction, allowing both foreign and domestic acquisitions, or a protectionist (P)-policy, only allowing domestic acquisitions. In the second stage, the government sells the state assets, denoted $k_{S}$. In the third stage, the foreign firm has the option of investing in new private assets, denoted $k_{P}$, in country $\mathrm{H}$, i.e. undertaking greenfield investments. Finally, in the fourth stage, both firms sell a homogenous product in the market in country $\mathrm{H}$, and the foreign firm faces a trade cost in addition to its normal production costs, unless it has invested in country $\mathrm{H}$.

Section 2.1 describes the oligopoly market, and the following sections present the greenfield investment decision and the privatization procedure. This acquisition-investmentproduct market interaction framework was developed in Norbäck and Persson (2003) which

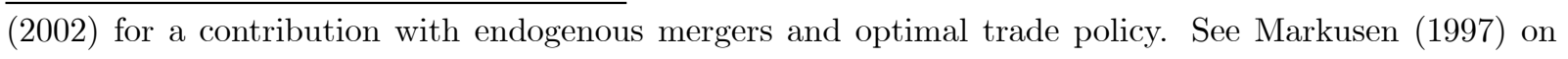
trade and investment policy. 


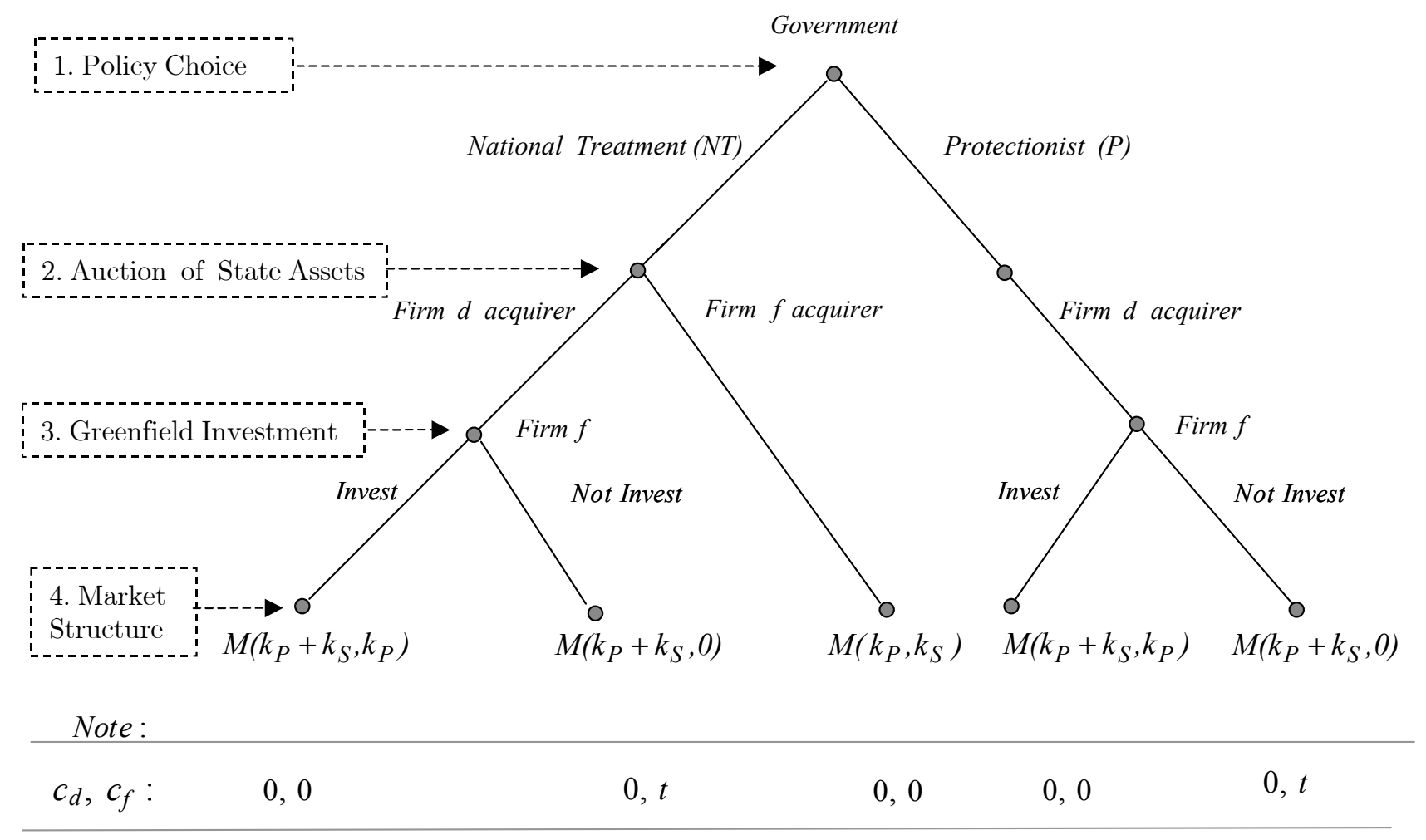

Figure 2.1: The four-stage game.

studied how the pattern of foreign and domestic acquisitions in the privatization depends on trade and greenfield investment costs. Here, we have extended this model into a policy framework and study the welfare effects of privatization, trade and investment policy.

\subsection{The Oligopoly market}

In stage four, firms compete in Cournot fashion in a homogenous good market. We assume firms to face a concave inverse demand function, so that $P^{\prime}(Q)<0$ and $P^{\prime \prime}(Q) \leq 0$. In Lemma 1, it is shown that the state assets will be sold at the auction in equilibrium. As illustrated by Figure 2.1, this implies that three different ownership structures are to be considered. To keep track of these, we denote the ownership structure where the domestic firm possesses $k_{d}$ units of assets and the foreign firm possesses $k_{f}$ units in country $\mathrm{H}$, by $M\left(k_{d}, k_{f}\right)$. For example, $M\left(k_{P}+k_{S}, 0\right)$ is then the duopoly where the domestic firm owns 
both private assets and the state assets, while the foreign firm has no assets in country $\mathrm{H}$ and exports from country F.

The last row in Figure 2.1 refers to the firms' marginal costs in the different ownership structures. A firm possessing at least one unit of assets in country $\mathrm{H}$ is assumed to produce at a zero marginal cost. However, the foreign firm has a cost disadvantage, $t$, per unit of output when serving the market from country $\mathrm{F}$, where $t$ captures the trade cost. We assume that the foreign firm can avoid trade costs when owning assets in country H, which can be achieved by acquiring the state assets $k_{S}$ or entering greenfield. These simplifying assumptions allow us to clearly attribute the effects of trade costs and greenfield costs, as opposed to, say, variable cost synergies effects.

Let $\pi_{i}^{D}\left(c_{i}, c_{j}\right)$ denote the duopoly (indicated by superscript $D$ ) profit for owner $i, j=$ $\{d, f\}$ when owner $i$ faces a variable $\operatorname{cost} c_{i}$ and owner $j$ faces a variable cost $c_{j}$. For example, $\pi_{d}^{D}(0, t)$ is then the profit for the domestic firm when it faces a zero variable cost and the foreign firm faces a variable cost $t \geq 0$. Let $t^{\max }$ be the $t$ satisfying $q_{f}^{D}(t, 0)=0$ and let $\pi_{i}^{M}(0)$ denote the monopoly profit when the monopolist faces a zero production cost.

\subsection{Greenfield investments}

The distinction between acquisition and greenfield investment will be central in the analysis, and will therefore be discussed in more detail before proceeding. The state assets are assumed to be (i) in fixed supply and (ii) of low value outside the industry. The latter is motivated by the fact that the state assets are likely to be designed to fit production in a particular industry and the cost of restructuring these into suitable assets in other industries is assumed to be high. ${ }^{11}$ These assumptions imply that the price of the state assets will be determined by their value within the industry.

On the other hand, the cost of greenfield investment is assumed to be fixed. This is

\footnotetext{
${ }^{11}$ To our knowledge, the only empirical paper studying sector-specific assets is Ramey and Shapiro (2001), which finds capital to be very specialized by sector.
} 
motivated by the fact that greenfield assets are created by new investments and that the supply of inputs (labor and capital) used to create greenfield assets are inputs used in many other industries in the economy. The investor in a particular industry could then be seen as price taker, i.e. facing an infinitely elastic supply.

More precisely, it is assumed that the foreign firm might undertake a greenfield investment in stage three at a fixed cost, $G$, if it did not obtain the state assets in stage two. The foreign firm then reduces its costs from $t$ to 0 by investing greenfield. Define $\bar{G}(t)$ as the value of the greenfield cost, such that the foreign firm is indifferent between the alternatives of supplying the market by exports or investing in new assets, $k_{P}$, and locally producing for the market. Formally, we thus have that:

$$
\bar{G}(t)=\left\{\begin{array}{cl}
\pi_{f}^{D}(0,0)-\pi_{f}^{D}(t, 0) & \text { if } t<t^{\max } \\
\pi_{f}^{D}(0,0) & \text { otherwise }
\end{array}\right.
$$

Since export profits $\pi_{f}^{D}(t, 0)$ decrease monotonically in $t$, the critical greenfield cost $\bar{G}(t)$ is increasing in $t$ and reaches its maximum at $t=t^{\max }$. For $t>t^{\max }$, the good is not exported (i.e. non-tradable) and $\bar{G}(t)=\pi_{f}^{D}(0,0)$.

\subsection{The privatization procedure}

Several western countries employed various kinds of auctions to sell state-owned enterprises to the highest bidder. In some transition countries, a substantial fraction of the shares of all firms was given to the general population for free. Most privatization programs combined several elements of these basic methods. ${ }^{12}$ In order to focus on the market forces as the determinants of the equilibrium market structure, we assume that the government sells the state assets to the highest bidder at an auction. More specifically, the privatization process in stage one is depicted as an auction where the two firms simultaneously post bids and the bidder with the highest bid obtains the state assets. If more than one firm posts such a bid, each such firm obtains the assets with equal probability. The winning

\footnotetext{
${ }^{12}$ See Schmidt and Schnitzer (1997).
} 
buyer pays an amount equal to his bid. The auctions will be solved for Nash equilibria in undominated pure strategies.

Let us now turn to the firms' valuations of the state assets. Some notation is required to define these valuations. We let $\pi_{i j}$ denote the profit made by firm $i$ when firm $j$ has acquired the state assets and $\pi_{i i}$ the profit made by firm $i$ when it has acquired the state assets itself. Then, the valuation for firm $i, v_{i}$, is defined: $v_{i} \equiv \pi_{i i}-\pi_{i j}$.

In the case with two firms in the industry, the analysis is straightforward as shown by the following lemma, proved in Norbäck and Persson (2003):

Lemma 1. Let firm $i$ be the firm with the highest valuation. The state assets are then acquired by firm $i$, at a price equal to the other firm's, firm $j$ 's, valuation of obtaining the state assets instead of firm $i, \mathcal{A}=v_{j}$.

\section{The Equilibrium Market Structure}

The game is solved backwards. We shall here only present a graphical solution of the Equilibrium Markets Structure (EMS), which is described in more detail in Table A.1. Given the critical level of the greenfield cost, $\bar{G}(t)$ defined in (2.1), three regions of interest emerge in the $G$ - $t$ space, as illustrated in Figure 3.1(ii).

In Figure 3.1(i), we depict the difference the foreign and the domestic firms' valuations of the state assets $v_{d}-v_{f}$, when Greenfield investments are not profitable for the foreign firm, $G>\bar{G}(t)$. As proved in Norbäck and Persson (2003), the difference in valuations $v_{d}-v_{f}$ then has a U-shape and the equation $v_{f}=v_{d}$ has two solutions, one with a strictly positive trade cost $t^{*}, 0<t^{*}<t^{\max }$ and one where $t^{*}=0$. The U-shape $v_{d}-v_{f}$ is due to two opposing forces. (i) There is an anti-competitive effect, where the domestic acquisition provides the domestic firm with higher market power in the product market when the trade cost is higher. The reason is that the domestic firm then faces a competitor with higher trade costs. (ii) The opposite force is the trade cost saving effect. A higher trade cost increases the foreign firm's incentive to acquire the domestic assets, since it can avoid 
a higher trade cost due to the acquisition.

It can be shown that at low trade costs, the trade-cost saving effect dominates the anti-competitive effect and the difference in valuations $v_{d}-v_{f}$ first decreases in trade costs, generating a foreign acquisition at the price $\mathcal{A}=v_{d}$, as $v_{d}<v_{f} \quad$ (Region 2 Figure 3.1(ii) ). At higher trade costs, however, the difference in valuations $v_{d}-v_{f}$ starts to rise as the anti-competitive effect begins to dominate the trade cost saving effects. At sufficiently high trade costs, $t>t^{*}, v_{d}>v_{f}$ which leads to a domestic acquisition at the price $\mathcal{A}=v_{f} \quad$ (Region 3 of Figure 3.1(ii)).

In the case of low greenfield costs, $G<\bar{G}(t)$, greenfield investment is profitable for the foreign firm. If the foreign firm has not obtained the state-assets, it will now switch from exports to greenfield production. This implies that the domestic firm can no longer prevent the foreign firm from enhancing its competitiveness in the product market and is thus not willing to pay for the state assets, i.e. $v_{d}=0$. In contrast, since the foreign firm can avoid the greenfield cost by an acquisition, its valuation is $v_{f}=G>0$. Therefore, the foreign firm obtains the state assets at price $\mathcal{A}=v_{d}=0$ (Region 1 in Figure 3.1(ii)).

\section{Policy}

The basic idea behind national treatment clauses is the commitment of countries to treat foreign-controlled firms operating in their territories no less favorably than domestic enterprises in similar situations. In the policy debate on FDI, it has been of some concern that FDI might "crowd out" domestic investments and shift profits from domestic to foreign firms. Here, we will illuminate the concept of national treatment in the context of privatizations. To this end, we compare, in Section 4.2, (i) a national treatment (NT) policy, where no discrimination between domestic and foreign buyers occurs, and (ii) a protectionist $(\mathrm{P})$ policy, where only domestic buyers are allowed to acquire the state assets. In order to demonstrate the value added of this analysis in relation to the existing literature, we first examine in section 4.1 the effects of National Treatment in a FDI model where 


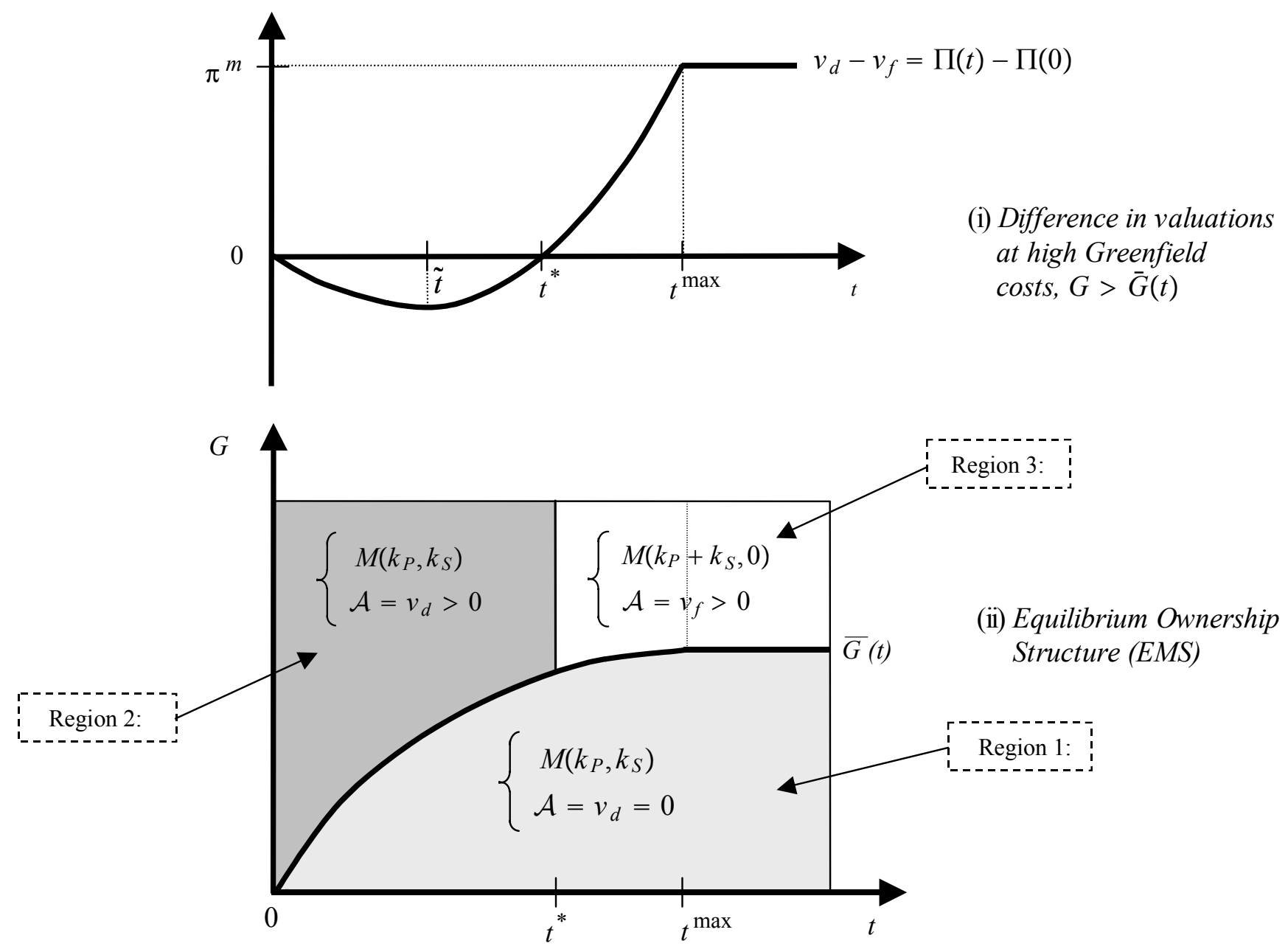

Figure 3.1: Illustrating the Equilibrium Market Structure (EMS). 
direct investment solely takes place by new investment at fixed costs, i.e. by greenfield investment. In section 4.3 we make a comparison between the NT policy and a partially discriminating policy, where the government retains a share of the privatized firm in case of a foreign acquisition.

Finally, section 4.4 examines the complications arising in the design of trade and investment policies in an environment where privatizations take place.

\subsection{A benchmark model: The Greenfield FDI-model}

As a benchmark, we start by studying the effects of an NT-policy in an FDI model where foreign entry can only take place by investing in greenfield assets at the fixed cost $G$. Under the protectionist policy, the domestic firm will then be a favored duopolist facing a rival that faces a trade cost. Under national treatment policy, the foreign firm is allowed to invest greenfield and if it does so, it becomes a strong local rival. It follows that the NTand P-policies only differ when, in equilibrium, the foreign firm invests greenfield under the NT policy, i.e. $G<\bar{G}(t)=\pi_{f}^{D}(0,0)-\pi_{f}^{D}(t, 0)$ is fulfilled.

The conventional domestic welfare evaluation of market structures in an international oligopoly is typically made by comparing the sum of domestic consumer surplus and domestic profits in different market structures. Let $W^{N T}$ denote the domestic welfare level when the foreign firm invests greenfield under the NT-policy, and let $W^{P}$ denote the corresponding welfare level under the P-policy, where only trade takes place. We then have:

$$
\begin{aligned}
W^{N T} & =C S(0)+\pi_{d}^{D}(0,0) \\
W^{P} & =C S(t)+\pi_{d}^{D}(0, t) .
\end{aligned}
$$

There are two terms in $W^{N T}$ in (4.1). The first is the consumer surplus when the foreign firm invests greenfield, which implies zero trade costs faced by the foreign firm and thus, $C S(0)$. The second term is the domestic firm's profit when the foreign firm invest greenfield, $\pi_{d}^{D}(0,0) . W^{P}$ in $(4.2)$ is derived in the same fashion, where it can be noted 
that the foreign firm then serves the domestic market facing trade costs and, hence, $C S(t)$ and $\pi_{d}^{D}(0, t)$. The difference in welfare between the two policies becomes:

$$
W^{N T-P}=[C S(0)-C S(t)]+\left[\pi_{d}^{D}(0,0)-\pi_{d}^{D}(0, t)\right]
$$

In general, the welfare differential in (4.3) cannot be signed: The consumer surplus is higher under the NT-policy, $C S(0)-C S(t) \geq 0$, due to strengthened product market competition. However, the domestic producer surplus is lower under the NT-policy, since the domestic firm's profit is reduced by the foreign firm's entry, $\pi_{d}^{D}(0,0)-\pi_{d}^{D}(0, t) \leq 0$. Hence, and as is illustrated in a linear Cournot model in the Appendix, we have the following results ${ }^{13}$ :

Lemma 2. Changing from a Protectionism policy to a National Treatment policy in the benchmark greenfield FDI model (i) increases domestic consumer surplus, (ii) decreases domestic producer surplus, and (iii) can increase as well as decrease domestic welfare

Proof. See Appendix.

\subsection{National Treatment Clauses in Privatizations}

Let us now turn to the study of an NT-policy in the full model described in section 2, where greenfield FDI (in stage two), as well as acquisition FDI (through the privatization in stage one), are considered. The sales price of the state assets is then added to the domestic welfare measure. Here, we study the privatization policy, that is, we compare the national treatment (NT) policy (where no discrimination between domestic and foreign buyers occurs) to the protectionist (P) policy (where only domestic buyers are allowed

\footnotetext{
${ }^{13}$ This complements the findings in Hoekman and Saggi (2002), which uses a set-up where FDI takes place through greenfield investment and the NT-policy concerns discriminatory output tax levied on FDI. They show how a discriminatory policy may be preferable since the government extracts foreign rents, while not affecting the foreign firm's mode of entry.
} 
to acquire the state assets). We assume that greenfield investments are allowed, while greenfield entry may or may not be profitable, i.e. $G \lesseqgtr \bar{G}(t)$.

It follows that the NT- and P-policies only differ when the foreign firm obtains the state assets under the NT-policy. The reason is that the price paid by the domestic firm when obtaining the state assets does not affect the welfare level, since it is only a transfer between the domestic firm and the domestic government.

Let $W_{f}^{N T}$ denote the domestic welfare level when the foreign firm obtains the state asset (indicated by subscript $f$ ) under the NT-policy, and let $W_{d}^{P}$ denote the corresponding welfare level when the domestic firm obtains the state asset (indicated by subscript $d$ ) under the P policy. Thus:

$$
\begin{aligned}
W_{f}^{N T} & =v_{d}+C S_{f}+\pi_{d f} \\
W_{d}^{P} & =C S_{d}+\pi_{d d}
\end{aligned}
$$

where we now use the more general definition of firm profits, $\pi_{i j}$, used in Section 2.3.

As shown in (4.4), there are three terms in $W_{f}^{N T}$. First, the sale of the state assets generates revenues when the foreign firm pays the acquisition price, which equals $v_{d}$ in equilibrium, i.e. the domestic firm's valuation of the state assets. The second term is the consumer surplus when the foreign firm is the equilibrium buyer, denoted $C S_{f}$, which depends on the trade cost faced by the foreign firm and thus, $C S_{f}=C S(0)$. Third, the domestic firm's profit when the state assets are in the hands of the foreign firm is $\pi_{d f}$. Finally note that $\pi_{d f}+v_{d}$ in (4.4) is the domestic producer surplus under the NT-policy. $W_{d}^{P}$ in (4.5) is derived in the same fashion, where it can be noted that $C S_{d}=C S(t)$.

Consequently, the welfare difference between the two policies becomes:

$$
\begin{aligned}
W^{N T-P} & =v_{d}-\left(\pi_{d d}-\pi_{d f}\right)+C S(0)-C S(t) \\
& =C S(0)-C S(t) \geq 0 .
\end{aligned}
$$

Consumers are better off under the NT-policy, since aggregate output will be higher in the market structure without trade costs. When greenfield entry is not credible, $G>$ 
$\bar{G}(t)$, foreign ownership increases the consumer surplus, since either the trade cost or the monopoly position of the domestic firm is avoided. When greenfield entry is credible, $G<\bar{G}(t)$, foreign and domestic ownership lead to the same level of consumer surplus under either firm's acquisition.

What are then the effects on domestic producer surplus? As is the case in the FDI model with only greenfield entry, the foreign firm's entry shifts profits from the domestic firm. However, here the foreign firm pays "an entry fee" through the acquisition price which can counteract this negative effect. In fact, as shown in (4.6), the acquisition price, $\mathcal{A}=v_{d}$, compensates for this negative profit shifting effect, since the foreign firm pays a price equal to the domestic firm's valuation of the state assets, $v_{d}$, which is exactly the negative impact on this firm of the decline in profits created by the foreign acquisition, $\pi_{d d}-\pi_{d f} \geq 0$.

Hence, we conclude:

Proposition 1. Changing from a Protectionism policy to a National Treatment policy in the privatization FDI model (i) increases domestic consumer surplus, (ii) does not affect domestic producer surplus, and (iii) increases domestic welfare.

Comparing the results in Proposition 1 and Lemma 2, suggests that the issue of national treatment in the context of acquisitions differs from that in the context of greenfield investments, since in the former, but not in the latter case, some of the rent shifting created by the investment is paid for by the foreign investor. More generally, it illustrates a fundamental difference between foreign entry in the context of acquisition and greenfield investment, respectively. In a greenfield entry, the foreign firm will pay a fixed entry cost, $G$, which only covers the opportunity cost in terms of factor inputs, and thus the negative effect on the domestic firm's profit is not "paid or compensated for". In contrast, in the case where entry takes place by an acquisition acquisition price, $\mathcal{A}=v_{d}$, can compensate for this negative profit shifting effect.

Let us now turn to world welfare, denoted by $V$, which can be derived by adding 
the foreign firm's profit under the two policies. Defining $V_{f}^{N T}$ as the world welfare level when the foreign firm invests greenfield under the NT-policy, and $V_{d}^{P}$ as denoting the corresponding welfare level under protectionism, we have:

$$
\begin{aligned}
V_{f}^{N T} & =C S_{f}+\pi_{d f}+\pi_{f f} \\
V_{d}^{P} & =C S_{d}+\pi_{d d}+\pi_{f d} .
\end{aligned}
$$

Note that we can disregard the selling price $\mathcal{A}=v_{d}$ from the world welfare measure, since the sales price of the state assets is just a redistribution from the foreign firm to the domestic government. Denoting the difference in world welfare, we then have that:

$$
\begin{aligned}
V^{N T-P} & =\left(\pi_{d f}+\pi_{f f}\right)-\left(\pi_{d d}+\pi_{f d}\right)+C S(0)-C S(t) \\
& =\Pi(0)-\Pi(t)+C S(0)-C S(t) \geq 0
\end{aligned}
$$

Once more, consumers are better off under the NT-policy since aggregate output will be higher in the market structure without trade costs. But the aggregate producer surplus will also be higher. To see this, note that according to Lemma 1, the foreign firm will obtain the state assets iff $v_{f}=\left(\pi_{f f}-\pi_{f d}\right)>\left(\pi_{d d}-\pi_{d f}\right)=v_{d}$. Again, since $v_{d}-v_{f}=$ $\pi_{d}^{D}(0, t)+\pi_{f}^{D}(t, 0)-\left[\pi_{d}^{D}(0,0)+\pi_{f}^{D}(0,0)\right]$, this implies that aggregate profit in the duopoly structure is higher under foreign ownership than under domestic ownership when the foreign firm obtains the state assets, that is $v_{d}-v_{f}<0$ iff $\Pi(0)>\Pi(t)$. This is also illustrated in Figure 3.1, where we note that the auction mechanism maximizes aggregate profits. Hence, we have the following results.

Proposition 2. Changing from a Protectionism policy to a National Treatment policy in the privatization FDI model (i) increases the world producer surplus and (ii) increases world welfare.

\subsection{Local Equity Requirements}

The results in the preceding section suggests that a national treatment policy in privatizations would often be preferred to a fully discriminatory policy. But other types of 
policies might be relevant alternatives. A partially discriminatory policy including a Local Equity Requirement (LER) might increase domestic welfare, since the domestic country then captures a share of the foreign firm's profit through its share holdings in the foreign firm. To study the effects of a LER, we assume that the government retains an $\alpha$ share of the foreign firm's profit when acquiring the privatized firm. In this section, we compare the NT-policy to the LER-policy, which approves foreign acquisition under the restriction that a certain share of the firm remains under domestic ownership. We first study the case where a foreign acquisition takes place under the NT- and the LER-policy. We then examine case where a foreign acquisition takes place under the NT and a domestic acquisition takes place under the LER policy.

\subsubsection{Comparing NT and LER policies when a foreign acquisition takes place under both policies.}

Let us start with the effects of a LER-policy on domestic welfare, which is determined by

$$
\begin{aligned}
W_{f}^{L E R} & =v_{d}+C S_{f}+\pi_{d f}+\alpha \pi_{f f} \\
& =W_{f}^{N T}+\alpha \pi_{f f} .
\end{aligned}
$$

A small increase in LER within this region then implies an increase in the domestic rents, since the government captures a share $\alpha$ of the foreign firms profit, while the acquisition price $^{14}$ is unaffected since it is determined by the domestic firm's willingness to pay. Furthermore, consumer surplus is unaffected, since the LER level does not affect the product market interaction in this interval. It follows from (4.9) that the LER-policy then increases domestic welfare as compared to the NT-policy. ${ }^{15}$

\footnotetext{
${ }^{14}$ Note that in a setting with several foreign firms, $\alpha$ might affect the acquisition price. The reason is that the acquisition price might then be determined by a foreign firm's willingness to pay which, in turn, depends on $\alpha$.

${ }^{15}$ Note that a local equity requirement can also benefit foreign firms, since it might protect them from confiscation. For instance, Konrad and Lommerud (2001) show, in an asymmetric information set-up, that an MNE might benefit from selling shares to locals, since it increases the parent multinational's
} 
We then turn to world welfare. Once more, we can just add foreign profits under the LER-policy to domestic welfare. Re-arranging, we have:

$$
V^{L E R}=C S(0)+\pi_{d f}+\alpha \pi_{f f}+(1-\alpha) \pi_{f f}=V^{N T},
$$

since $\alpha \pi_{f f}$ is merely a redistribution of profits from the foreign firm to the government. Hence:

Proposition 3. For a given ownership structure, imposing local equity requirements (i) increases domestic welfare and (ii) has no effect on world welfare.

\subsubsection{Comparing NT and LER policies when the LER policy leads to a do- mestic acquisition}

Imposing a local equity requirement will also (for some parameter values) have an effect on the equilibrium ownership of the state assets. This is illustrated in Figure 4.1, where we yet again make use of the graphical framework developed in Figure 3.1. First, note that if the government imposes a LER, this will decrease the incentive for foreign acquisitions. Note that for $G>\bar{G}(t)$, the foreign firm's valuation adjusted for the LER becomes, $v_{f}^{L E R}=(1-\alpha) \pi_{f f}-\pi_{f d}$. Hence, the locus showing the difference in valuations $v_{d}-v_{f}^{L E R}$ shifts upwards in Figure 4.1 when $\alpha$ increases. Due to the U-shape of $v_{d}-v_{f}^{L E R}$, this implies that the region of foreign acquisition decreases for both low and medium size trade costs (shifting the ownership structure from $M\left(k_{P}, k_{S}\right)$ in Region 2 to $M\left(k_{P}+k_{S}, 0\right)$ in Region 3).

To examine the welfare effect when the LER induces domestic ownership, note that the difference in welfare for this parameter range (the marked regions in Figure 4.1) becomes:

$$
\begin{aligned}
W^{N T-L E R} & =\left[C S(0)+v_{d}+\pi_{d f}\right]-\left[C S(t)+\pi_{d d}\right] \\
& =C S(0)-C S(t) \geq 0 .
\end{aligned}
$$

information rent which is protected from a host government's confiscatory taxation. 
Since the LER induces domestic ownership, the domestic country now neither captures any foreign product market profits nor are any auction revenues from the foreign firm extracted. Moreover, the domestic firm's acquisition leads to a lower consumer surplus, since the price in the product market will be higher. It then follows that, in this case, the LER policy is equivalent to the P-policy and hence, the NT-policy leads to higher domestic welfare.

Turning to world welfare, accounting for both foreign profits and domestic welfare (and again noting that the acquisition price $\mathcal{A}$ and the retained profit $\alpha \pi_{f f}$ is merely a redistribution of profits from the foreign firm to the government), we have:

$$
\begin{aligned}
V^{N T-L E R} & =\left[C S(0)+\pi_{d f}+\pi_{f f}-\left[C S(t)+\pi_{d d}+\pi_{f d}\right]\right. \\
& =C S(0)-C S(t)+\pi_{d f}+\pi_{f f}-\left[\pi_{d d}+\pi_{f d}\right] \\
& =C S(0)-C S(t)+\Pi(0)-\Pi(t) \geq 0
\end{aligned}
$$

Once more, consumers are better off under the NT-policy since aggregate output will be higher in the market structure without trade costs. But the aggregate producer surplus will also be higher. Again applying Lemma 1, the foreign firm will obtain the state assets iff $v_{f}=\left(\pi_{f f}-\pi_{f d}\right)>\left(\pi_{d d}-\pi_{d f}\right)=v_{d}$. Since $v_{d}-v_{f}=\pi_{d}^{D}(0, t)+\pi_{f}^{D}(t, 0)-$ $\left[\pi_{d}^{D}(0,0)+\pi_{f}^{D}(0,0)\right]$, this implies that aggregate profit in the duopoly structure is higher under foreign ownership than under domestic ownership when the foreign firm obtains the state assets, i.e. $v_{d}-v_{f}<0$ iff $\Pi(0)>\Pi(t)$.

This gives us the following results:

Proposition 4. (i) A local equity requirement (LER) can lead to a change from a foreign to a domestic acquisition of the privatized firm. (ii) If a LER induces domestic acquisitions, a change from a LER-policy to an NT policy increases domestic and world welfare.

\subsection{Investment and Trade Policies}

The preceding section dealt with the preferred buyer, taking investment and trade policy as given. We now elaborate on trade and investment policy, taking the privatization-auction, 


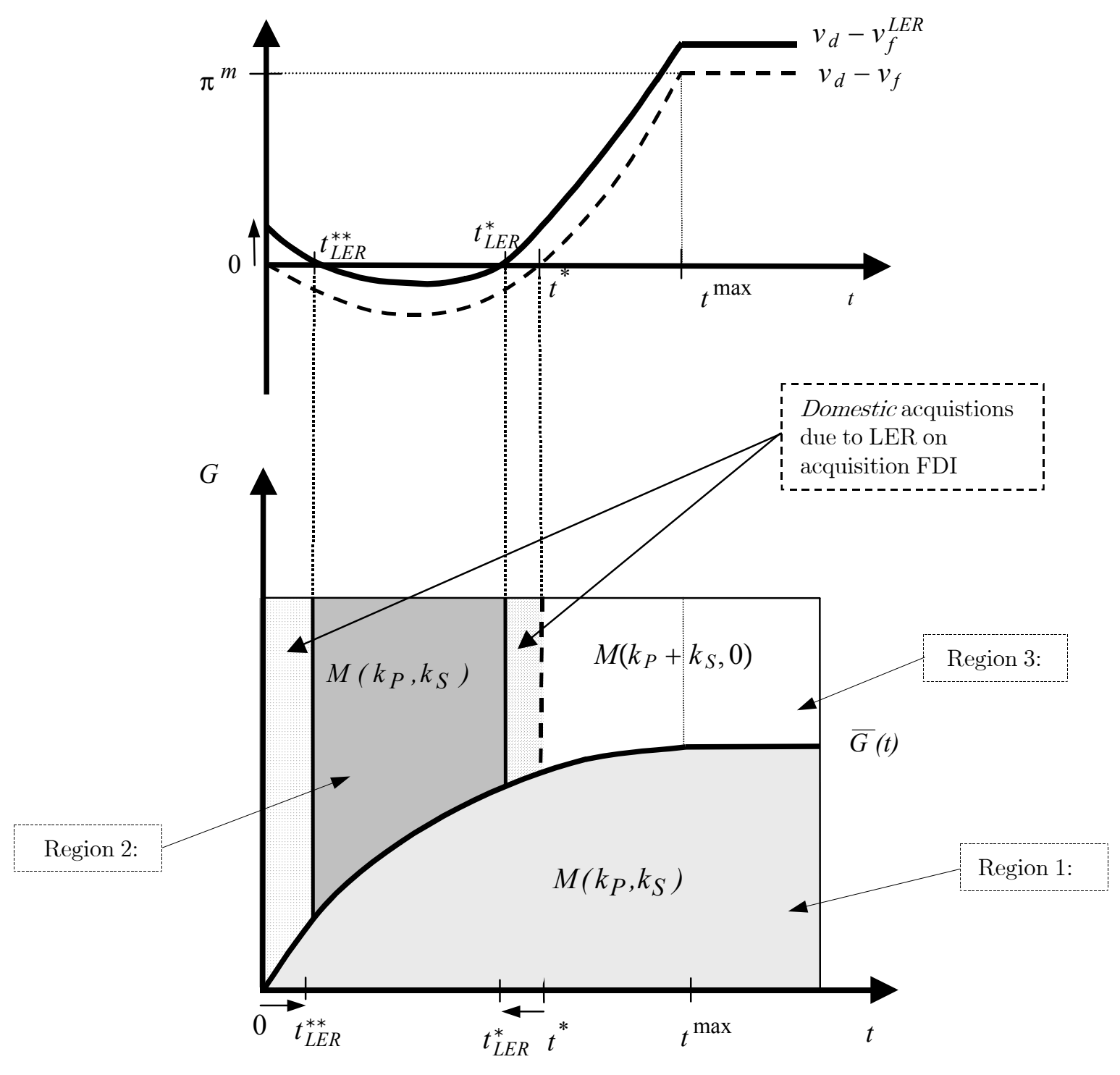

Figure 4.1: The effect of a local equity requirement on the Equilibrium Market Structure (EMS). 
defined in Section 2.3, as given. Hence, we assume the NT-policy in the privatization to be given. We also focus on domestic welfare. Governments can affect investment costs in numerous ways. For instance, location subsides and tax reductions can contribute to lower investment costs. Trade policy can be performed by using tariffs or employing various measures inhibiting import competition, such as border controls. We here assume that the government can affect the greenfield cost, $G$, and the trade cost, $t$, the foreign firm must face. In order to highlight the strategic effects of the investment and trade policy, subsidies or taxes are assumed not to directly affect the government's budget. Welfare is then given by

$$
W=\left\{\begin{array}{c}
v_{d}+C S_{f}+\pi_{d f}, \quad \text { when the foreign firm obtains the state assets. } \\
C S_{d}+\pi_{d d}, \quad \text { when the domestic firm obtains the state assets. }
\end{array}\right.
$$

Investment and trade policy will not only affect the firms' incentives for greenfield investment and exports, ${ }^{16}$ but will also affects the sales price at the auction. In Figure 4.2, we illustrate how welfare is affected by investment and trade policy, in the linear Cournot model, which is described in the Appendix. The corresponding equilibrium ownership structures are indicated by arrows.

\subsubsection{Trade policy}

Trade costs will affect both the price paid at the auction and the buyer's identity. For instance, if greenfield costs are sufficiently high and trade costs are low, as in Region 2 of Figure 4.2, the foreign firm obtains the state assets. A small increase in trade costs within this region then implies that the foreign firm still obtains the state assets, but must pay a higher price for these assets, since the domestic firm's valuation has increased due to the increased anti-competitive effect of higher trade costs, i.e. $\frac{d \mathcal{A}}{d t}=\frac{d v_{d}}{d t}=\frac{d\left[\pi_{d}^{D}(0, t)-\pi_{d}^{D}(0,0)\right]}{d t}>0$. Consequently, there is an increase in welfare, since the product market equilibrium is unaffected.

\footnotetext{
${ }^{16}$ See, for instance, Markusen (1997).
} 


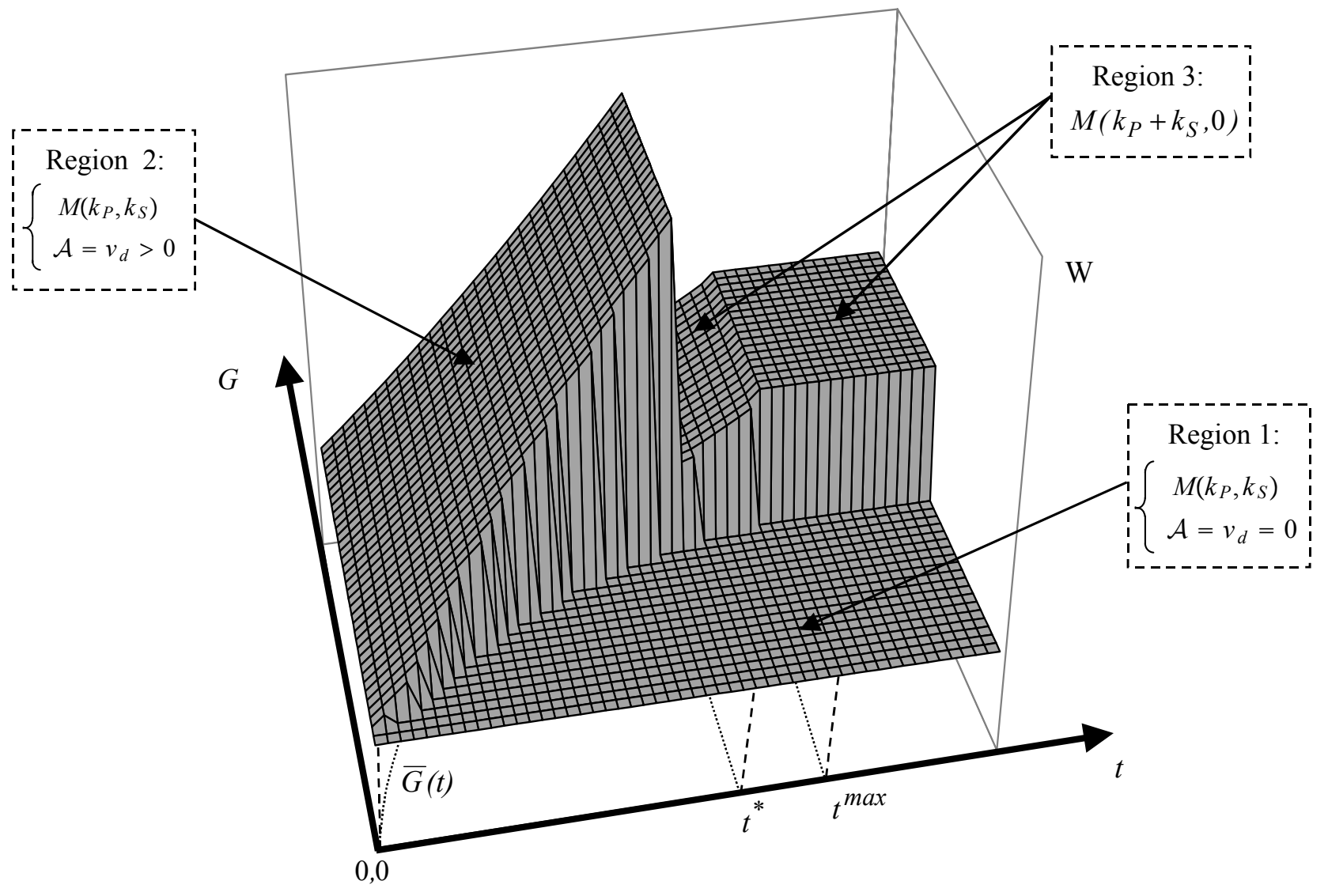

Figure 4.2: Illustrating the effects on domestic welfare of trade and investment policy. 
However, a larger increase in the trade cost might lead to the domestic firm obtaining the state assets (shifting the ownership structure in Figure 4.2 from $M\left(k_{P}, k_{S}\right)$ in Region 2 to $M\left(k_{P}+k_{S}, 0\right)$ in Region 3$)$. The government then no longer extracts foreign profits. Moreover, the domestic firm's acquisition leads to a lower consumer surplus, since the price in the product market will be higher. These two effects outweigh the effect of increased profits for the domestic firm, thereby leading to lower aggregate welfare, as shown in Figure 4.2 .

Alternatively, if trade costs are increased for medium size investment costs, an increased tariff might also lead to the foreign firm having a credible threat of investing greenfield when not acquiring the state assets (moving within the same ownership structure $M\left(k_{P}, k_{S}\right)$ from Region 2 to Region 1 in Figure 4.2). Since the domestic firm cannot gain protection by an acquisition, this leads to a complete loss of sales revenues as the domestic firm's valuation of the state assets and, hence, the acquisition price fall to zero, i.e. $\mathcal{A}=v_{d}=0 .{ }^{17}$ In this case, welfare decreases since the product market equilibrium is unaffected.

Thus, we have the following result: ${ }^{18}$

Proposition 5. Trade barriers might reduce domestic welfare, since these do not necessarily improve the domestic firm's market position, but only reduce the sales price of the state assets.

\subsubsection{Investment policy}

Investment subsidies might also reduce welfare, even when leading to increased investments and when associated with no direct costs. Again, this occurs because at lower investment costs the foreign firm obtains a credible threat of investing greenfield when not acquiring

\footnotetext{
${ }^{17}$ Ellingsen and Wärneryd (1999) show that an import-competing industry may not want maximal protection, since it might trigger greenfield FDI.

${ }^{18}$ Note that this result would not be affected if revenues were assumed to be generated from trade costs, since no exports take place in equilibrium.
} 
the state assets. Hence, the domestic firm's valuation of the state assets and the acquisition price falls to zero, $\mathcal{A}=v_{d}=0$ (again, moving within the same ownership structure $M\left(k_{P}, k_{S}\right)$ from Region 2 to Region 1 in Figure 4.2). This implies that the government can no longer extract foreign profits. Since the product market equilibrium is unaffected, we have the following result:

Proposition 6. Investment subsidies to foreign firms might reduce domestic welfare, since these do not necessarily increase investments but only reduce the sales price of the state assets.

\subsubsection{Discussion}

The issue of the optimal design of the policy towards foreigners is not addressed in this paper. However, our analysis points at some noteworthy observations concerning how different policies towards foreigners interact.

First, common to the benchmark model, the above analysis illustrates that the domestic producer surplus could be higher absent the possibility of greenfield investments. More specifically, Figure 4.2 shows that an increased greenfield cost can increase welfare by increasing the acquisition price, i.e. shifting the EMS from Region 1 to, for instance, Region 2 in Figure 4.2. This follows from the fact that $\mathcal{A}=v_{d}>0$ for $G>\bar{G}(t)$, whereas if Greenfield investment is feasible, $G \leq \bar{G}(t)$, the acquisition price becomes $\mathcal{A}=v_{d}=0$. In the latter case, the domestic firm's low (zero) valuation of the state assets simply reflects that the domestic firm cannot protect its market by an acquisition, since it will face a low profit regardless of the outcome of the privatization.

Second, a policy which blocks both foreign greenfield entry and acquisition entry might also increase domestic welfare for some parameter values in the model. To see this, note that if we are initially in Region 1 in Figure 4.2 a total ban on FDI (restricting foreign greenfield investment as well as foreign acquisitions) would increase domestic welfare as this would provide a level of welfare corresponding to the one in Region 3. 
Third, the highest welfare level would be reached by allowing foreign acquisitions but ensuring high greenfield costs and medium high trade costs, since the peak level of welfare of Region 2 in Figure 4.2 would then be reached. The reason is that the sales price increases with the trade costs in this interval, as it leads to a stronger anti-competitive effect (and thus a high valuation of the state assets by the domestic firm).

However, the complexity of the externalities involved indicates that deriving an optimal policy would be very involved and would require the government to be very well-informed.

\section{Concluding remarks}

This paper studies the impact on welfare of introducing "National Treatment" (NT) clauses in privatizations (which set out the commitments of countries to treat foreign-controlled firms operating in their territories no less favorably than domestic enterprises in similar situations). In the policy debate on foreign direct investment (FDI), it has been a concern that these investments might "crowd out" domestic investments and shift profits from domestic to foreign firms. The paper points to the fact that the potentially negative effects of an NT policy through crowding out are partly mitigated in privatizations, since the negative impact on domestic firms from the acquisition is partly paid for by the foreign investor in the bidding competition over the state assets. However, it is shown that a partially discriminatory policy such as Local Equity Requirement (LER) could increase domestic welfare in situations where the market structure is not affected by the LER. In such cases, foreign rents are extracted though the acquisition price as well as by retaining partial domestic ownership of the privatized firm. However, a LER could also be counterproductive by preventing welfare-enhancing foreign acquisitions, since LER will reduce the profitability of a foreign acquisition.

An NT policy in privatizations is also shown to lead to higher total aggregate producer surplus for domestic and foreign agents, since the privatization auction is shown to be conducive to high total industry profits. Moreover, the consumer surplus tends to be 
higher under the NT-policy, since foreign entry is facilitated and thereby product market competition is also strengthened. Consequently, both domestic and world welfare tend to be higher under a NT-policy compared to the P-policy.

It should, however, be noted that these findings do not imply that an NT policy in privatizations always leads to higher domestic and world welfare. The domestic firm might be the socially preferred buyer if there are several domestic and foreign firms, since the buyer does not pay for the aggregate externalities created by its acquisition. Moreover, if domestic and foreign firms differ in other respects than location, such as market shares or various possibilities of achieving cost savings, a discriminatory policy will under some circumstances be better than a NT policy. This might be the case if a foreign acquisition creates larger negative externalities on rivals and less positive externalities on consumers than a domestic acquisition. However, our analysis indicates that there seems to be no a priori reason to treat foreign firms very differently from domestic firms in privatizations. Rather, it seems warranted to investigate whether rules incurring a higher level of welfare than those rules only using information about nationality, might be found, for instance, using measures from the practise of the competition law, such as firms' market shares, and different firms' various possibilities of achieving cost savings.

\section{References}

[1] Ellingsen, T. and Wärneryd, K., 1999, "Foreign Direct Investment and the Political Economy of Protection", International Economic Review, 40, 357-379.

[2] Hoekman, B. and Saggi, K., 2002, "Trade versus Direct Investement: Modal Neutrality and National Treatment, CEPR Discussion Paper No. 3375.

[3] Horn, H. and Levinsohn, J., 2001, "Merger Policies and Trade Liberalization", Economic Journal, 111, 244-276. 
[4] Horn, H. and Persson, L. 2001, "The Equilibrium Ownership of an International Oligopoly," Journal of International Economics, Vol 53, No. 2.

[5] Horstmann, I. and J. Markusen, 1992, Endogenous Market Structures in International Trade (Natura Facit Saltum), Journal of International Economics 32, 109-129.

[6] Huck, S. and Konrad, K. A., 2002, "Merger Profitability and Trade Policy, Mimeo, WZB.

[7] Konrad, K. A. and K. E. Lommerud, 2001, "Foreign direct investment, intra-firm trade and ownership structure," European Economic Review 45, 475-494.

[8] Markusen, J. R., 1997, "Trade versus Investment Liberalization," National Bureau of Economic Research Working Paper No. 6231.

[9] Norbäck, P. J. and Persson L, 2003, "Privatization and Foreign Competition", forthcoming, Journal of International Economics.

[10] Ramey, V. A., and Shapiro, M. D., 2001, "Displaced Capital: a study of Aerospace Plant Closing.", Journal of Political Economy, vol 109, 958-99.

[11] Schmidt, K., M., and Schnitzer, M., 1997, "Methods of Privatization: Auctions, Bargaining and Give-aways," Discussion Paper 1541, Centre for Economic Policy Research.

[12] Thomson Financial Securities Data, Mergers \& Acquisitions Database, 2001.

[13] UNCTAD, World Investment Report 1998, 1999 and 2000, (United Nations Conference on Trade and Development, Geneva).

[14] Vickers, J, and Yarrow, G., 1991, "Economic Perspectives on Privatization", Journal of Economic Perspectives, Vol.5, No. 2, 111-132. 


\section{A. Appendix}

\section{A.1. The Equilibrium Market Structure (EMS)}

In table A.1, we show how the Equilibrium Market Structure (EMS), that is, the Equilibrium Byuer (EB), the Equilibrium Ownership Structure (EOS) and the Acquisition price $(\mathcal{A})$, are derived. For further details, see Norbäck and Persson (2003).

Table A.1: The Equilibrium Market Structure (EMS).

\begin{tabular}{|c|c|c|c|}
\hline & Region 1: & Region 2: & Region 3: \\
\hline Def: & $G<\bar{G}(t)$ & $\begin{array}{l}G>\bar{G}(t) \\
0<t<t^{*}\end{array}$ & $\begin{array}{l}G>\bar{G}(t) \\
t>t^{*}>0\end{array}$ \\
\hline$v_{d}:$ & $\pi_{d}^{D}(0,0)-\pi_{d}^{D}(0,0)$ & $\pi_{d}^{D}(0, t)-\pi_{d}^{D}(0,0)$ & $\begin{array}{l}\pi_{d}^{D}(0, t)-\pi_{d}^{D}(0,0): t<t^{\max } \\
\pi_{d}^{M}(0): t>t^{\max }\end{array}$ \\
\hline$v_{f}:$ & $\begin{array}{l}\pi_{f}^{D}(0,0)- \\
{\left[\pi_{f}^{D}(0,0)-G\right]}\end{array}$ & $\pi_{f}^{D}(0,0)-\pi_{f}^{D}(t, 0)$ & $\begin{array}{l}\pi_{f}^{D}(0,0)-\pi_{f}^{D}(t, 0): t<t^{\max } \\
\pi_{f}^{D}(0,0): t>t^{\max }\end{array}$ \\
\hline EB: & $f$ & $f$ & $d$ \\
\hline $\mathcal{A}:$ & $v_{d}$ & $v_{d}$ & $v_{f}$ \\
\hline EOS: & $M\left(k_{P}, k_{S}\right)$ & $M\left(k_{P}, k_{S}\right)$ & $\left\{\begin{array}{l}M\left(k_{S}+k_{P}, k_{P}\right): t<t^{\max } \\
M\left(k_{S}+k_{P}, 0\right): t>t^{\max }\end{array}\right.$ \\
\hline$\pi_{d}$ & $\pi_{d}^{D}(0,0)$ & $\pi_{d}^{D}(0,0)$ & $\left\{\begin{array}{c}\pi_{d}^{D}(0, t): t<t^{\max } \\
\pi_{d}^{M}(0): t>t^{\max }\end{array}\right.$ \\
\hline$\pi_{f}$ & $\pi_{f}^{D}(0,0)$ & $\pi_{f}^{D}(0,0)$ & $\left\{\begin{array}{l}\pi_{f}^{D}(t, 0): t<t^{\max } \\
0: t>t^{\max }\end{array}\right.$ \\
\hline
\end{tabular}

\section{A.2. The linear Cournot model}

In Table A.2, below, we derive the EMS using a linear Cournot model. 


\section{A.2.1. Trade and investment policies in the full model}

For the welfare calculation in Figure 4.2, it can be noted that quantities can be recovered as $q_{i}^{D}=\frac{a-2 c_{i}+c_{j}}{3 b}$ and $q_{i}^{m}=\frac{a-c_{i}}{2 b}$ and that the consumer surplus is then $C S_{i}=\frac{1}{2} Q_{i}^{2}$, where $C S_{i}$ is the consumer surplus and $Q_{i}=q_{i}+q_{j}$ the total quantity produced, when firm $i$ obtains the state assets. To derive Figure 4.2, we have set $a=b=1$. Finally, in table A.2, we have used the notation $c_{f}^{A}$ for the marginal cost of the foreign firm when it acquires the state assets, and $c_{f}^{G}$ and $c_{f}^{E}$ as the marginal cost when this firm is investing greenfield and exporting, respectively.

\section{A.2.2. Proof of Lemma 2 for the benchmark model}

To prove Lemma 2, it is straightforward to show that (4.3) using the linear demand $P=a-b\left(q_{i}+q_{j}\right)$ given in Table A.2, becomes

$$
\begin{aligned}
W^{N T-P} & =[C S(0)-C S(t)]+\left[\pi_{d}^{D}(0,0)-\pi_{d}^{D}(0, t)\right] \\
& =\frac{1}{18} t \frac{4 b a+2 b t-4 a+t}{b^{2}}
\end{aligned}
$$

It follows that $W^{N T-P}>0$ iff $t>4 a \frac{1-b}{2 b+1}$. This implies that if $b$ and $t$ are sufficiently small, the protectionist policy increases domestic welfare. 
Table A.2: The linear Cournot model.

\begin{tabular}{lc}
\hline \hline Demand: & $P=a-b\left(q_{i}+q_{j}\right)$ \\
$\pi_{i}^{D}:$ & $b\left(\frac{a-2 c_{i}+c_{j}}{3 b}\right)^{2}$ \\
$\pi_{i}^{m}$ & $b\left(\frac{a-c_{i}}{2 b}\right)^{2}$ \\
$c_{d}:$ & 0, \\
$c_{f}^{h}:$ & $c_{f}^{A}=c_{f}^{G}=0<t=c_{f}^{E}$ \\
\hline
\end{tabular}

Critical greenfield investment, critical trade costs:

$\bar{G}(t): \quad\left\{\begin{array}{c}\frac{4(a-t)}{9 b} t: t<t^{\max }, \\ b\left(\frac{a}{2}\right)^{2}: t>t^{\max }\end{array}\right.$

$t^{\max }: \quad \frac{a}{2}$

Low greenfield costs, $G<\bar{G}(t)$ : [ Region 1 in Figures 3.1, 4.1 and 4.2 ]

$v_{d}-v_{f}: \quad-G<0$

High greenfield costs, $G>\bar{G}(t), 0<t<t^{\max }:[$ Regions 2 and 3 in Figures 3.1, 4.1 and 4.2 ]

$v_{d}-v_{f}: \quad-\frac{(2 a-5 t)}{9 b} t\left\{\begin{array}{l}<0: t<t^{*}, \\ >0: t>t^{*}\end{array}\right.$

$t^{*}: \quad \frac{2 a}{5}$

$\tilde{t}: \quad \frac{a}{5}$

High Greenfield costs, $G>\bar{G}(t), t>t^{\max }>0$ : [Region 3 in Figures 3.1, 4.1 and 4.2 ]

$v_{d}-v_{f}: \quad \frac{a^{2}}{36 b}>0$

Note: $\quad$ Parameter values in Figure 4.2 are: $a=b=1, a-c=1$ 